\title{
Correlation between programmed cell death ligand1 (PD-L1) expression and clinical parameters in colorectal carcinoma
}

\author{
Zainab Waleed Aziz Al-hayali', Asmaa Mohammadsheet Mahmood', Zahraa Osama Yahiya', Wahda Moham- \\ med Taib Al -Nuaimy²
}

\footnotetext{
Department of pathology, Ninevah Medical College, Ninevah University, Mosul, Iraq.

${ }^{2}$ Department of Pathology, College of Medicine, University of Mosul, Nineveh Province, Iraq.

Corresponding author: Zainab Waleed Aziz Al-hayali (Email: zainabwaleed90@yahoo.com )
}

\begin{abstract}
Objectives: Programmed cell death ligand1 (PD-L1) tissue expression in colorectal cancer (CRC) displays conflicting results among various studies. We aimed to identify the rate of PD-L1 positivity in colorectal carcinoma, and its immune infiltrating cells, their relationship with clinicopathological parameters of patients, and to correlate the results with other studies.

Methods: PD-L1 antibody retrospectively analyzed immunohistochemically in tissue microarray blocks of 99 specimens with colonic and rectal carcinomas operated between January 2015 and December 2017. A comparison performed between PD-L1 expression in tumor cells (TCS) as well as tumor-infiltrating immune cells (TIICS) for age, sex, histological differentiation, the primary tumor location, number of involved lymph nodes, angiolymphatic invasion, and TNM stage.

Results: Of the 99 patients, the median age was 54.5 (range: 18-3) years. Fourteen samples were PD-L1 positive in TCs, increased to 32\% in TIICS. A significant expression of PD-L1 in TCs was correlated with medullary histology $(p=0.03)$, number of the involved lymph nodes ( $p=$ 0.02), distant metastasis $(p=0.001)$, and TNM stage $(p=0.0001)$. The PD-L1 status in TIICs was again connected with adverse clinical and pathological parameters.

Conclusions: The expression of PD-L1 in TCs and TIICs is associated significantly with advanced cancer or lymphatic invasion in patients who underwent surgery after a diagnosis of CRC. The research designates the significance of estimation of TCs and TIICs in correlation to clinicopathological characteristics of patients a finding that could produce a piece of evidence for precise electing immunotherapy.

Keywords: Programmed cell death ligand1, Colorectal carcinoma, Tissue microarray study, Immunohistochemistry.
\end{abstract}

\section{Introduction}

Colorectal cancer (CRC) is one of the most frequent malignant tumors worldwide, accounting for nearly $19.7 \%$ of whole cancers and $8.9 \%$ of cancer deaths. ${ }^{1}$ The evolution of cancer is affected by the sequence of events including both epigenetic and inherited epithelial cells changes and is also directed by tumor-host interaction. ${ }^{2}$ The strong reaction of tumor-infiltrating immune cells in blocking tumor dissemination is a familiar model of this interaction. ${ }^{2}$ However, certain types of malignancies have the ability to escape immune response through the upregulation of the host immune checkpoints in the tumor microenvironment. ${ }^{3}$

Programmed cell death1 ligand1 (PD-L1, CD274) is a key immune checkpoint transmembrane physiological ligand for programmed-death1 (PD1), expressed by lymphocytes, macrophages, and dendritic cells. ${ }^{2,}{ }^{4}$ The PD-1/PD-L1 interaction plays an important role in the inhibition of $\mathrm{T}$ cell-mediated immune response leading to the exhaustion of effectors $\mathrm{T}$ cells ${ }^{2}$. It is also expressed in various malignancies, serve as a receptor transferring an anti-apoptotic signal to guard tumor cells against apoptosis and immune escape of tumor cells. ${ }^{2}$ The PD1-PDL1 pathway, therefore, has been involved in cancer progression. ${ }^{5}$

This observation leads to the production of PD1-PDL1 pathway inhibitors to counteract tumor cells of evading from host immune responses, and to intensify antitumor immunity, thus providing a promising approach in oncology toward immunotherapy. ${ }^{6}$ It is noted that expression of PD-L1, by tumor-infiltrating immune cells (TIICs), and or neoplastic cells, affects patients' prognosis in several cancers and correlates with a therapeutic response. ${ }^{7}$ Nonetheless, the role concerning PD-L1 tissue expression in CRC and its microenvironment in correspondence with clinicopathological characteristics remains elucidated with different studies reporting conflicting results. ${ }^{6,8,9}$

Therefore, the aim of the current study is to investigate PD-L1 immunoexpression in CRC, and its microenvironment, and to reveal whether there is a correlation between them with variable clinicopathological parameters.

\section{Materials and Methods}

\section{Patients and primary tissue specimens characteristics}

A retrospective tissue microarrays study carried out on 99 formalin-fixed, paraffin-embedded specimens of colonic and rectal carcinoma, obtained at random from the department of pathology laboratories at Azadi Teaching Hospital and some own clinical laboratories in Duhok City, Iraq during the period between January 2015 and December 2019.

We maintained a routine protocol and proper ethics approval from the Medical Research Ethics Committee, College of Medicine, University of Mosul (approval number UOM/COM/MRECL2019(8), date 17/2/2020), to access the clinicopathological data included: patient age, sex, the primary site of the tumor, histological differentiation, the number of the involved lymph nodes, angiolymphatic invasion, and TNM stage. The pathologic staging based on the 8th edition of the American Joint Committee on Cancer staging manual. ${ }^{10}$ 


\section{Tissue microarray construction}

In the current study, two independent pathologists retrospectively analyzed H\&E stained slides and selected the representative archival paraffin-embedded blocks for each case. Four cases were excluded due to lack of sufficient tissue in the block.

Tissue microarray (TMA) blocks made with a hand-operated TMA kit(3DHistech Manual TMA Kit) includes two ingredients (Puncher extractor device and Moulder). ${ }^{11}$ During the procedure, $2 \mathrm{~mm}$ in diameter three tissue cores were selected from regions of concern in paraffin-embedded tissues using a hollow needle, along with those of normal colonic tissue as negative controls All tissue cores arranged in recipient paraffin blocks (TMA blocks). Subsequently, sections of $3 \mu \mathrm{m}$ from this block were cut, mounted then transferred to glass slides. Later 2 TMA block sections were chosen one was stained with hematoxylin-eosin to confirm the histology and to certify the tumor tissue availability ( $\geq 50 \%$ of the core area) in the slide while another slide submitted to PD-L1 immunohistochemistry test.

\section{Immunohistochemistry technique}

Immunohistochemical (IHC) staining was performed on TMA sections with Dako automated Autostainer Link 48 with ZytoChem Plus HRP Polymer Kit detection system used in the work of the current study Briefly, $3 \mu \mathrm{m}$ TMA thick sections were baked overnight at $58{ }^{\circ} \mathrm{C}$, deparaffinized in xylene, rehydrated through graded ethanol. A pretreatment procedure was performed later on the tissue sections with heat-induced epitope retrieval (HIER), hindered for endogenous peroxidase activity in $3 \%$ hydrogen peroxide solution at $37^{\circ} \mathrm{C}$ for $10 \mathrm{~min}$, ensued by high-pressure cooking in citrate antigen retrieval solution $(\mathrm{pH}=6.0)$ for about $10 \mathrm{~min}$ for PD-L1. Tissue sections were incubated at $37{ }^{\circ} \mathrm{C}$ for $60 \mathrm{~min}$ with rabbit IgG monoclonal antibodies against PD-L1 (1:100, Cat. No.RBK063-05, Zytomed systems, Berlin, Germany). Immunostaining was performed using the ZytoChem Plus HRP polymer (DAB) (POLHRP-006, Zytomed systems, Berlin, Germany), in which a brown-colored precipitate appeared at the antigen site. Finally, counterstaining and blueing with hematoxylin (SigmaAldrich, St Louis, MO, USA), and mounting in a non-aqueous mounting medium. ${ }^{8}$

\section{Scoring of PD-L1 immunohistochemical expression}

PD-L1 positivity designated as cells with membranous and/ or cytoplasmic immunohistochemical staining on $\geq 5 \%$ of all TCs or TIICs. ${ }^{12}$ Trivial changes observed in the staining intensity, therefore, was not estimated.

PD-L1 immunoexpression on tumor cells (TCs), and tumor-infiltrating immune cells (TIICs) was analyzed separately. TIICs were designated as lymphocytes, macrophages, and dendritic cells infiltrating nests of neoplastic cells. ${ }^{8}$

\section{Statistical analyses}

Statistical analyses using the SPSS statistical package for Social Sciences (version 18.0 for Windows, SPSS, Chicago, IL, USA) were performed. Analysis of the data was made by using the $t$-test and Chi-square test. The microsatellite instability (MSI) status and the relapse/survival free relapse were unknown; thus, not assessed.
All $p$-values considered statistically significant when retained less than or equal to $0.05 .^{12}$

\section{Results}

\section{Clinical characteristics of patients}

The baseline clinicopathological characteristics of 99 primary CRC samples are listed within Table 1 . Briefly, the median age was 54.5 years (range 18-83 years old), by the dominance of males $(55.5 \%)$, with a male to female ratio $1.25: 1$. The predominant primary tumor locations were the right colon (34.3\%), and the rectum (31.3\%). Histologically, there were $93.9 \%$ moderate to poorly differentiated adenocarcinoma, $15.1 \%$ of which show medullary type. Most of the tumors invade through the muscularis propria into the pericolorectal tissues (T3 and $\mathrm{T} 4 \%=84.8 \%$ ). Fifty cases were presented with regional lymph node involvement by metastatic disease. Approximately $7.1 \%$ of cases were at stage IV.

Table 1. Clinicopathological characteristics of CRC patients.

\begin{tabular}{|c|c|}
\hline Variables & Sample no. \\
\hline $\begin{array}{l}\text { Age ( years) } \\
\text { Mean }\end{array}$ & 54.5 \\
\hline $\begin{array}{l}\text { Gender } \\
\text { Female } \\
\text { Male }\end{array}$ & $\begin{array}{l}44 \\
55\end{array}$ \\
\hline $\begin{array}{l}\text { Tumor location } \\
\text { Lt colon } \\
\text { Rectum } \\
\text { Right colon } \\
\text { Transverse colon }\end{array}$ & $\begin{array}{l}28 \\
31 \\
34 \\
6\end{array}$ \\
\hline $\begin{array}{l}\text { Medullary type } \\
\text { Yes } \\
\text { No }\end{array}$ & $\begin{array}{l}15 \\
84\end{array}$ \\
\hline $\begin{array}{l}\text { Tumor differentiation } \\
\text { Well } \\
\text { Moderate } \\
\text { Poor }\end{array}$ & $\begin{array}{l}6 \\
80 \\
13\end{array}$ \\
\hline $\begin{array}{l}\text { Primary tumor }(\mathrm{pT}) \\
\text { T2 } \\
\text { T3 } \\
\text { T4 }\end{array}$ & $\begin{array}{l}15 \\
77 \\
7\end{array}$ \\
\hline $\begin{array}{l}\text { No .of involved lymph nodes } \\
\text { Mean }\end{array}$ & 3.18 \\
\hline $\begin{array}{l}\text { Angio-lymphatic invasion } \\
\text { Negative } \\
\text { Positive }\end{array}$ & $\begin{array}{l}30 \\
69\end{array}$ \\
\hline $\begin{array}{l}\text { Regional lymph node (pN) } \\
\text { N0 } \\
\text { N1 } \\
\text { N2 }\end{array}$ & $\begin{array}{l}49 \\
28 \\
22\end{array}$ \\
\hline $\begin{array}{l}\text { Distant metastasis (pM) } \\
\text { M0 } \\
\text { M1 }\end{array}$ & $\begin{array}{l}91 \\
8\end{array}$ \\
\hline $\begin{array}{l}\text { TNM Stage } \\
\text { I } \\
\text { II } \\
\text { III } \\
\text { IV }\end{array}$ & $\begin{array}{l}9 \\
40 \\
43 \\
7\end{array}$ \\
\hline
\end{tabular}




\section{Immunohistochemical expression of PD-L1}

The PD-L1 staining was at various frequencies both within TCs and TIICs. With a $\geq 5 \%$ cut-off, tumor cells were positive in $14 \%$ of specimens, while in $32 \%$ of TIICs. The normal colonic mucosa did not show any staining. Cytoplasmic and/ or membranous staining was observed in positive TCs cells and TIICs with the predominance of the former. In TCs, focal PD-L1 positive pattern was prevailing. However, in TIICs the diffuse positivity was the most common. The expression of PD-L1 is shown in Figures 1 and 2.
The correlation between the expression of PD-L1 within TCs and the clinicopathological parameters shown in Table 2. On TCs, expression of PD-L1 was significantly linked with medullary histology ( $p=0.03)$, number of the involved lymph nodes $(p=0.02)$, distant metastasis $(p=0.001)$, and TNM stage $(p=0.0001)$. On the contrary, other variables such as age, gender, primary tumor location, tumor differentiation, angiolymphatic invasion, and regional lymph node $(\mathrm{pN})$ status were of no significance, although primary tumor $(\mathrm{pT})$ status approached the borderline of significance $(p=0.07)$.
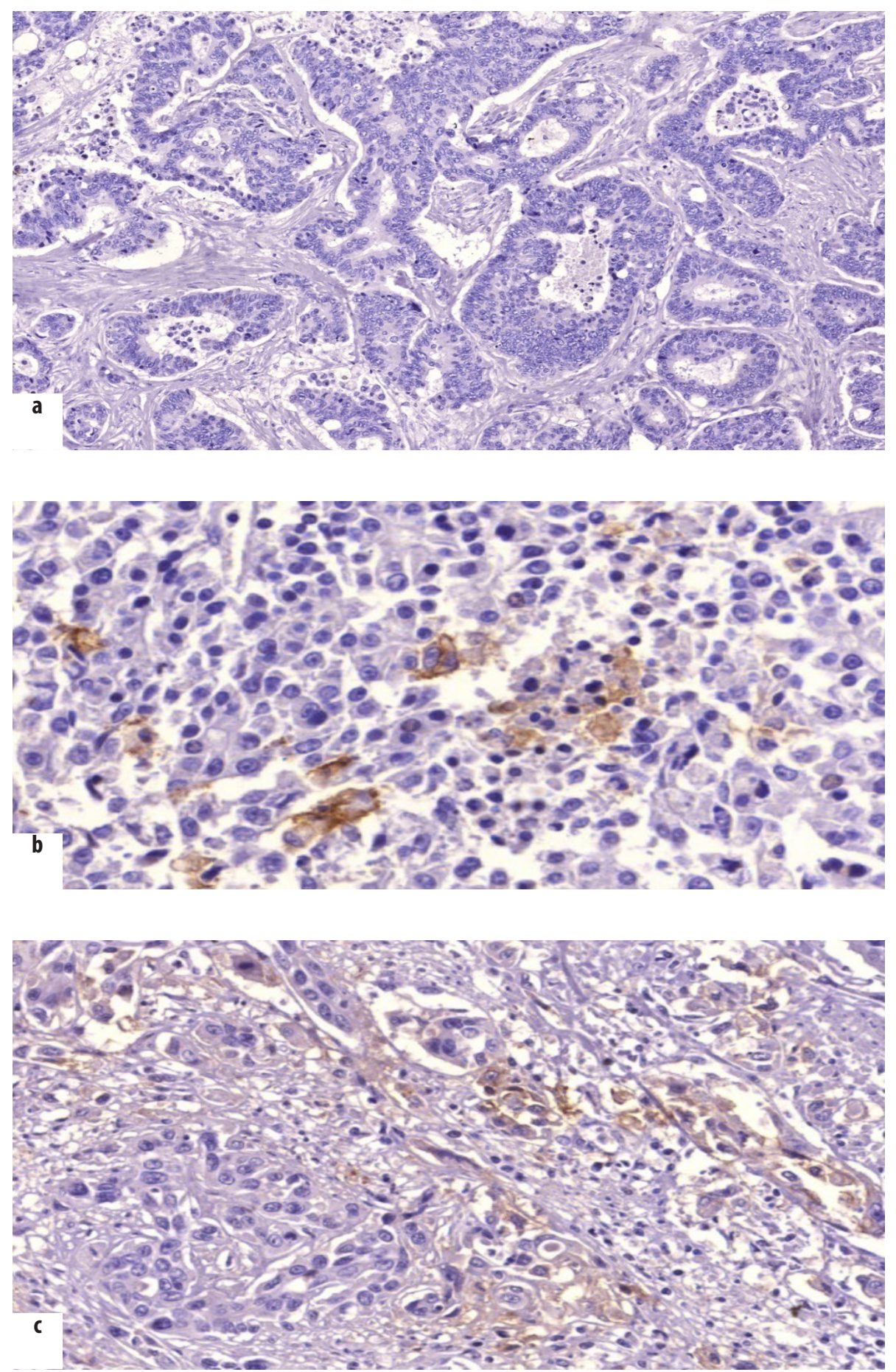

Figure 1. Programmed cell death ligand-1 immunohistochemical expression in CRC neoplastic cells (original magnification, $\times 100, \times 400$ ). (a) A lack of PD-L1 expression; (b) negative PD-L1 expression ( $<5 \%$ of stained cells); (arrows); (c) positive PD-L1 expression ( $\geq 5 \%$ of stained cells). 

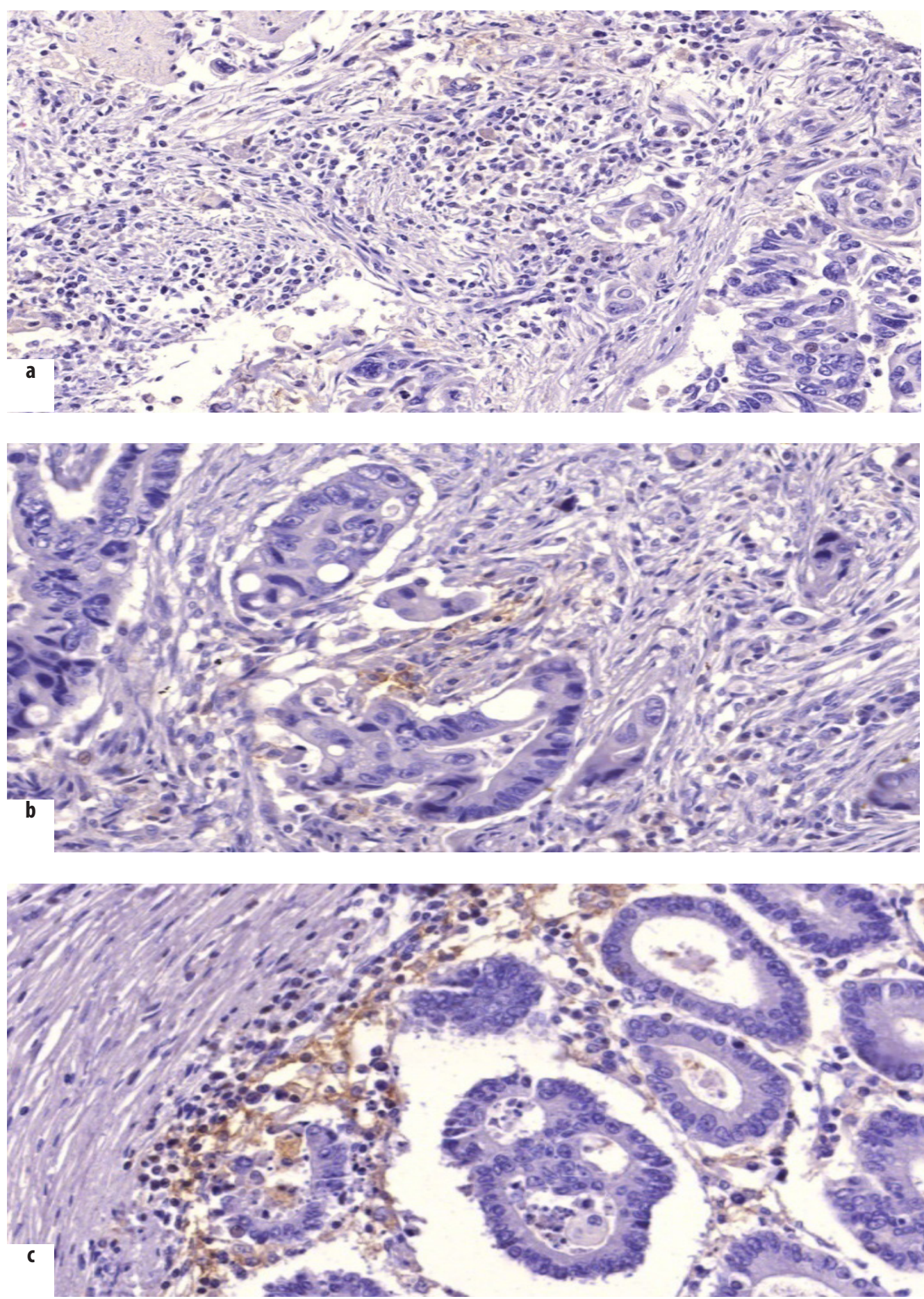

Figure 2. Programmed cell death ligand-1 immunohistochemical expression in colorectal carcinoma immune cells (original magnification, $\times 400$ ). (a) A lack of PD-L1 expression; (b) focal PD-L1 expression ( $<5 \%$ of stained cells); (arrow); (c) positive PD-L1 expression ( $\geq 5 \%$ of stained cells).

The PD-L1 status in TIICs was studied and its association with the variable clinical and pathological features of CRC patients were analyzed (Table 3). The TIICs exhibited higher PD-L1 immunoexpression were significantly associated with medullary histology $(p=0.01)$, primary tumor $(\mathrm{pT})$ status $(p=0.05)$, regional lymph node $(\mathrm{pN})$ status $(p=0.04)$, angiolymphatic invasion $(p=0.02)$, distant metastasis $(p=0.002)$, and TNM stage $(p=0.002)$ while other variables provided no significant association.

\section{Discussion}

In oncology, the detection of a prognostic and predictive biomarker remains very important to select patients who benefit from a given therapy while sparing others. In this rapidly evolving field, PD-L1 becomes one of the emerging biomarkers that play a major role in immune evasion and distant metastasis. ${ }^{9}$ However, the role of this biomarker is less clear in colorectal cancer, as to whether its expression indicates a better or worse 


\begin{tabular}{|c|c|c|c|}
\hline \multirow[b]{2}{*}{ Variable } & \multicolumn{2}{|c|}{ PD-L1 expression in tumor cell (TC) } & \multirow[b]{2}{*}{ P-value } \\
\hline & $\begin{array}{c}\text { (Negative) } \\
\mathrm{N}=85(85.9 \%)\end{array}$ & $\begin{array}{c}\text { (positive) } \\
\mathrm{N}=14(14.1 \%)\end{array}$ & \\
\hline Age, mean \pm SD & $53.68 \pm 16.85$ & $56.57 \pm 8.06$ & 0.3 \\
\hline $\begin{array}{l}\text { Gender } \\
\text { Female } \\
\text { Male }\end{array}$ & $\begin{array}{l}35(79.5 \%) \\
50(90.9 \%)\end{array}$ & $\begin{array}{c}9(20.5 \%) \\
5(9.1 \%)\end{array}$ & 0.09 \\
\hline $\begin{array}{l}\text { Tumor location } \\
\text { Lt colon } \\
\text { Rectum } \\
\text { Right colon } \\
\text { Transverse colon }\end{array}$ & $\begin{array}{l}26(92.9 \%) \\
28(90.3 \%) \\
27(79.4 \%) \\
4(66.7 \%)\end{array}$ & $\begin{array}{l}2(7.1 \%) \\
3(9.7 \%) \\
7(20.6 \%) \\
2(33.3 \%)\end{array}$ & 0.2 \\
\hline $\begin{array}{c}\text { Medullary type } \\
\text { No } \\
\text { Yes }\end{array}$ & $\begin{array}{l}75(90.2 \%) \\
10(66.7 \%)\end{array}$ & $\begin{array}{l}9(10.8 \%) \\
5(33.3 \%)\end{array}$ & 0.03 \\
\hline $\begin{array}{c}\text { Tumor differentiation } \\
\text { Well } \\
\text { Moderate } \\
\text { Poor }\end{array}$ & $\begin{array}{l}5(83.3 \%) \\
70(87.5 \%) \\
10(76.9 \%)\end{array}$ & $\begin{array}{c}1(16.7 \%) \\
10(12.5 \%) \\
3(23.1 \%)\end{array}$ & 0.5 \\
\hline $\begin{array}{l}\text { Primary tumor }(\mathrm{pT}) \\
\text { T2 } \\
\text { T3 } \\
\text { T4 }\end{array}$ & $\begin{array}{c}13(86.7 \%) \\
68(88.3 \%) \\
4(57.1 \%)\end{array}$ & $\begin{array}{l}2(13.3 \%) \\
9(11.7 \%) \\
3(42.9 \%)\end{array}$ & 0.07 \\
\hline No .of involved lymph nodes, mean \pm SD & $2.66 \pm 4.53$ & $5.84 \pm 6.45$ & 0.02 \\
\hline $\begin{array}{c}\text { Angio-lymphatic invasion } \\
\text { Negative } \\
\text { Positive }\end{array}$ & $\begin{array}{l}28(93.3 \%) \\
57(82.6 \%)\end{array}$ & $\begin{array}{c}2(6.7 \%) \\
12(17.4 \%)\end{array}$ & 0.1 \\
\hline $\begin{array}{l}\text { Regional lymph node (pN) } \\
\text { N0 } \\
\text { N1 } \\
\text { N2 }\end{array}$ & $\begin{array}{l}45(91.8 \%) \\
23(82.1 \%) \\
17(77.3 \%)\end{array}$ & $\begin{array}{l}4(8.2 \%) \\
5(17.9 \%) \\
5(22.7 \%)\end{array}$ & 0.2 \\
\hline $\begin{array}{l}\text { Distant metastasis (pM) } \\
\text { M0 } \\
\text { M1 }\end{array}$ & $\begin{array}{l}83(91.2 \%) \\
2(25.0 \%)\end{array}$ & $\begin{array}{c}8(8.8 \%) \\
6(75.0 \%)\end{array}$ & 0.001 \\
\hline $\begin{array}{c}\text { TNM Stage } \\
\text { I } \\
\text { II } \\
\text { III } \\
\text { IV }\end{array}$ & $\begin{array}{l}9(100.0 \%) \\
37(92.5 \%) \\
37(86.0 \%) \\
2(28.6 \%)\end{array}$ & $\begin{array}{c}- \\
3(7.5 \%) \\
6(14.0 \%) \\
5(71.4 \%)\end{array}$ & 0.0001 \\
\hline
\end{tabular}

${ }^{*} P \leq 0.05 \mathrm{~S}$

prognosis. ${ }^{13,14}$ Besides, PD-L1 expression in an association with the clinical and pathological features are not well-defined in such tumor. In this study, PD-L1 positivity recognized in $14 \%$ of the patients with colorectal carcinoma. This result is agreed by two prior studies published very comparable issues with PD-L1 immunoexpression in $14.6 \%$ and $12 \%$ of cases, respectively. ${ }^{12,15}$ In contrast, Masugi et al. analyzed 823 rectal and colonic cancer cases and noticed PD-L1 tissue expression in $89 \%$ of them. ${ }^{16}$ These discrepancies might be due to the various scoring systems, positivity cut-offs applied, intratumoral staining heterogeneity, and the different antibodies used. ${ }^{12}$

In terms of histopathological parameters, PD-L1 in TCs was significantly associated with medullary histology, number of the involved lymph nodes, distant metastasis, and advanced stage. Interestingly, a nice research by $\mathrm{Zhu}$ et $\mathrm{al}^{17}$ has also pointed that high PD-L1 expression in tumor cells is correlated significantly with the metastatic progression, advancement of tumor stage, and poor outcomes in CRCs.

Although PD-L1 expression was more common in rightsided tumors with female predominance similar to previous studies, ${ }^{3,18}$ they didn't approach a statistic significance. From our point of view, this attributed to the small sample size of the study.

On the contrary, other variables such as age, tumor differentiation, angiolymphatic invasion, and regional lymph node status were of no significance compatible with Shan et al. ${ }^{19}$ According to our study, these findings indicate that PD-L1 expression in TCs is closely linked to aggressive histological features in CRC in consistence with other studies that linked PD-L1 expression to unfavorable prognosis. ${ }^{9,}{ }^{15}$ However, these studies did not evaluate PD-L1 expression on immune cells, which now implemented in the scoring strategy for numerous 


\begin{tabular}{|c|c|c|c|}
\hline \multirow{2}{*}{ Variable } & \multicolumn{2}{|c|}{$\begin{array}{l}\text { PD-L1 expression in tumor infiltrating immune cells } \\
\text { (TIICs) }\end{array}$} & \multirow{2}{*}{ P-value } \\
\hline & $\begin{array}{c}\text { (Negative) } \\
\mathrm{N}=67(67.7 \%)\end{array}$ & $\begin{array}{c}\text { (Positive) } \\
\mathrm{N}=32(32.3 \%)\end{array}$ & \\
\hline Age, mean \pm SD & $15.61 \pm 16.63$ & $53.00 \pm 14.46$ & 0.6 \\
\hline $\begin{array}{l}\text { Gender } \\
\text { Female } \\
\text { Male }\end{array}$ & $\begin{array}{l}28(63.6 \%) \\
39(70.9 \%)\end{array}$ & $\begin{array}{l}16(36.4 \%) \\
16(29 . \% 1)\end{array}$ & 0.2 \\
\hline $\begin{array}{c}\text { Tumor location } \\
\text { Lt colon } \\
\text { Rectum } \\
\text { Right colon } \\
\text { Transverse colon }\end{array}$ & $\begin{array}{l}21(75.0 \%) \\
26(83.9 \%) \\
18(52.9 \%) \\
2(33.3 \%)\end{array}$ & $\begin{array}{c}7(25.0 \%) \\
5(16.1 \%) \\
16(47.1 \%) \\
4(66.7 \%)\end{array}$ & 0.1 \\
\hline $\begin{array}{l}\text { Medullary type } \\
\text { No } \\
\text { Yes }\end{array}$ & $\begin{array}{l}61(72.6) \\
6(40.0 \%)\end{array}$ & $\begin{array}{l}23(27.4) \\
9(60.0 \%)\end{array}$ & 0.1 \\
\hline $\begin{array}{c}\text { Tumor differentiation } \\
\text { Well } \\
\text { Moderate } \\
\text { Poor }\end{array}$ & $\begin{array}{l}4(66.7 \%) \\
57(71.3 \%) \\
6(46.2 \%)\end{array}$ & $\begin{array}{l}2(33.3 \%) \\
23(28.8 \%) \\
7(53.8 \%)\end{array}$ & 0.2 \\
\hline $\begin{array}{l}\text { Primary tumor }(\mathrm{pT}) \\
\text { T2 } \\
\text { T3 } \\
\text { T4 }\end{array}$ & $\begin{array}{l}12(80.0 \%) \\
53(68.8 \%) \\
2(28.6 \%)\end{array}$ & $\begin{array}{l}3(20.0 \%) \\
24(31.2 \%) \\
5(71.4 \%)\end{array}$ & 0.05 \\
\hline No .of involved lymph nodes, mean \pm SD & $2.50 \pm 4.61$ & $4.40 \pm 5.37$ & 0.07 \\
\hline $\begin{array}{c}\text { Angio-lymphatic invasion } \\
\text { Negative } \\
\text { Positive }\end{array}$ & $\begin{array}{l}25(83.3 \%) \\
42(60.9 \%)\end{array}$ & $\begin{array}{l}5(16.7 \%) \\
27(39.1 \%)\end{array}$ & 0.02 \\
\hline $\begin{array}{c}\text { Regional lymph node (pN) } \\
\text { N0 } \\
\text { N1 } \\
\text { N2 }\end{array}$ & $\begin{array}{l}38(77.6 \%) \\
18(64.3 \%) \\
11(50.0 \%)\end{array}$ & $\begin{array}{l}11(22.4 \%) \\
10(35.7 \%) \\
11(50.0 \%)\end{array}$ & 0.04 \\
\hline $\begin{array}{c}\text { Distant metastasis (pM) } \\
\text { M0 } \\
\text { M1 }\end{array}$ & $\begin{array}{c}66(72.5 \%) \\
1(12.5 \%)\end{array}$ & $\begin{array}{l}25(27.5 \%) \\
7(87.5 \%)\end{array}$ & 0.002 \\
\hline $\begin{array}{c}\text { TNM Stage } \\
\text { I } \\
\text { II } \\
\text { III } \\
\text { IV }\end{array}$ & $\begin{array}{l}9(100.0 \%) \\
30(75.0 \%) \\
27(62.8 \%) \\
1(14.3 \%)\end{array}$ & $\begin{array}{c}- \\
10(25.0 \%) \\
16(37.2 \%) \\
6(85.7 \%)\end{array}$ & 0.002 \\
\hline
\end{tabular}

${ }^{*} P \leq 0.05 S$

neoplasms like triple-negative breast cancers. ${ }^{20}$ Moreover, the prognostic value regarding PD-L1 positivity in these immune cells still awaits investigations. ${ }^{21}$ To address these questions, we separately studied PD-L1 immunoexpression in TIICs and correlated the results with the clinicopathological data of the patients.

The results identified PD-L1 positivity in $32 \%$ of the tumor immune cells. This immunoexpression was significantly associated with medullary histology, angiolymphatic invasion, distant metastasis, and advanced stage. So, again connected with adverse clinical and pathological parameters. Lin et $\mathrm{al}^{22}$ and Wang et $\mathrm{al}^{23}$ reported similar results but not in Masugi et al. ${ }^{16}$

The metastatic progression and advancement of tumor stage in CRC patients with PD-L1 positive tumor infiltrating immune cells could be explained by the fact that such expression might lead to the inhibition of activated T lymphocytes and immune evasion, thus to poor outcomes. ${ }^{24,25}$ Another possible explanation is that alteration of the intestinal microbes by some abnormal intestinal status may induce a shift in the immunologic function accordingly. ${ }^{26}$ Therefore, intestinal dysfunction as a consequence of CRC may modify the intestinal immune system.

So, from our point of view, our findings highlight support to the hypothesis that PD-L1 expression correlated with the poor clinical and pathological features in colorectal carcinoma, because we also shed lights on the frequency of PD-L1 positivity in TIICs in rectal and colonic carcinomas, rather than TCs alone. It suggested that patients with advanced cancer or lymphatic invasion were more likely to express PD-L1.

The current study has some limitations that are somewhat of small sample size (99 cases), its retrospective nature as well 
as the MSI status, and the relapse/survival free relapse not addressed.

However, to our knowledge, no similar study has conducted in Iraq, despite the relatively high prevalence of colorectal carcinoma.

To achieve further strong evidence, sizable well-designed cohort studies and investigations on PD-L1 immunoexpression on TIICs, are required.

\section{Conclusions}

The immunoexpression of PD-L1 in TCs and its microenvironment is associated significantly with advanced cancer or lymphatic invasion in patients who underwent surgery after a diagnosis of CRC. The research designates the significance of estimation of TCs and TIICs together in correlation to clinicopathological characteristics of patients, a finding that could produce a piece of evidence for precise electing patients toward immunotherapy, aiming for better outcomes.

\section{Statement Conflict of Interest:}

No conflict of interest.

\section{Funding Statement:}

No funding.

\section{References}

1. Bray F. Ferlay J, Soerjomataram I, Siegel RL, Torre LA, Jemal A. Global cancer statistics 2018: GLOBOCAN estimates of incidence and mortality worldwide for 36 cancers in 185 countries. CA Cancer J Clin. 2018;68:394-424.

2. Schott DS, Pizon M, Pachmann U, Pachmann K. Sensitive detection of PD-L1 expression on circulating epithelial tumor cells (CETCS) could be a potential biomarker to select patients for treatment with PD-1/PD-L1 inhibitors in early and metastatic solid tumors. Oncotarget. 2017;8(42):72755.

3. Valentini AM, Di Pinto F, Cariola F, Guerra V, Giannelli G, Caruso ML, et al. PDL1 expression in colorectal cancer defines three subsets of tumor immune microenvironments. Oncotarget. 2018;9(9):8584.

4. Topalian SL, Hodi FS, Brahmer JR, Gettinger SN, Smith DC, McDermott DF, et al. Safety, activity, and immune correlates of anti-PD-1 antibody in cancer. New Engl J Med. 2012;366(26):2443-54

5. Bertucci F, Finetti P, Mamessier E, Pantaleo MA, Astolfi A, Ostrowski J, et al. PDL1 expression is an independent prognostic factor in localized GIST. Oncoimmunology. 2015;4(5):e1002729.

6. Zhou C, Tang J, Sun H, Zheng X, Li Z, Sun T, et al. PD-L1 expression as poor prognostic factor in patients with non-squamous non-small cell lung cancer. Oncotarget. 2017:8(35):58457.

7. Gatalica Z, Snyder C, Maney T, Ghazalpour A, Holterman DA, Xiao N, et al. Programmed cell death 1 (PD-1) and its ligand (PD-L1) in common cancers and their correlation with molecular cancer type. Cancer Epidemiol Prev Biomarkers. 2014;23(12):2965-70

8. Li Y, Liang L, Dai W, Cai G, Xu Y, Li X, et al. Prognostic impact of programed cell death-1 (PD-1) and PD-ligand 1 (PD-L1) expression in cancer cells and tumor infiltrating lymphocytes in colorectal cancer. Mol Cancer 2016:15(1):55.

9. Song M, Chen D, Lu B, Wang C, Zhang J, Huang L, et al. PTEN loss increases PD-L1 protein expression and affects the correlation between PD-L1 expression and clinical parameters in colorectal cancer. PLoS One. 2013;8(6):e65821.

10. Amin MB, Edge SB. AJCC cancer staging manual: springer; 2017.

11. Shaban ZM, Al-Aubaidy SR, Hameedi AD. Idh1 mutation in gliomas in baghdad by immunohistochemical study. Int J Genet Genomics. 2018;6(1):1-7.

12. Inaguma S, Lasota J, Wang Z, Felisiak-Golabek A, Ikeda H, Miettinen M Clinicopathologic profile, immunophenotype, and genotype of CD274 (PDL1)-positive colorectal carcinomas. Modern Pathol. 2017:30(2):278-85.

13. Rosenbaum MW, Bledsoe JR, Morales-Oyarvide V, Huynh TG, Mino-Kenudson M. PD-L1 expression in colorectal cancer is associated with microsatellite instability, BRAF mutation, medullary morphology and cytotoxic tumorinfiltrating lymphocytes. Modern Pathol. 2016;29(9):1104-12.

14. Droeser RA, Hirt C, Viehl CT, Frey DM, Nebiker C, Huber X, et al. Clinical impact of programmed cell death ligand 1 expression in colorectal cancer. Eur J Cancer. 2013:49(9):2233-42.

15. Lee KS, Kim BH, Oh HK, Kim DW, Kang SB, Kim H, et al. Programmed cell death ligand-1 protein expression and CD 274/PD-L1 gene amplification in colorectal cancer: Implications for prognosis. Cancer Sci. 2018;109(9):295769.

16. Masugi Y, Nishihara R, Yang J, Mima K, Da Silva A, Shi Y, et al. Tumour CD274 (PD-L1) expression and T cells in colorectal cancer. Gut. 2017;66(8):1463-73.

17. Zhu H, Qin H, Huang Z, Li S, Zhu X, He J, et al. Clinical significance of programmed death ligand-1 (PD-L1) in colorectal serrated adenocarcinoma. Int J Clin Exp Pathol. 2015;8(8):9351-9. PubMed PMID: 26464688. Pubmed Central PMCID: PMC4583920. Epub 2015/10/16. eng.

18. Elfishawy M, Abd ESA, Hegazy A, El-Yasergy DF. Immunohistochemical expression of programmed death ligand-1 (PDL-1) in colorectal carcinoma and its correlation with stromal tumor infiltrating lymphocytes. Asian Pacific J Cancer Prev : APJCP. 2020 Jan 1;21(1):225-32. PubMed PMID: 31983188 Pubmed Central PMCID: PMC7294013. Epub 2020/01/28. eng.

19. Shan T, Chen S, Wu T, Yang Y, Li S, Chen X. PD-L1 expression in colon cancer and its relationship with clinical prognosis. Int J Clin Exp Pathol. 2019;12(5):1764-9. PubMed PMID: 31933995. Pubmed Central PMCID: PMC6947132. Epub 2020/01/15. eng.

20. Kowanetz M, Zou W, Gettinger SN, Koeppen H, Kockx M, Schmid P, et al. Differential regulation of PD-L1 expression by immune and tumor cells in NSCLC and the response to treatment with atezolizumab (anti-PD-L1). Proc Natl Acad Sci. 2018;115(43):E10119-E26.

21. Lee LH, Cavalcanti MS, Segal NH, Hechtman JF, Weiser MR, Smith JJ, et al. Patterns and prognostic relevance of PD-1 and PD-L1 expression in colorectal carcinoma. Modern Pathol. 2016;29(11):1433-42.

22. Lin $H$, Wei $S$, Hurt EM, Green MD, Zhao L, Vatan L, et al. Host expression of PD-L1 determines efficacy of PD-L1 pathway blockade-mediated tumor regression. J Clin Investig. 2018;128(2):805-15.

23. Wang L, Ren F, Wang Q, Baldridge LA, Monn MF, Fisher KW, et al. Significance of programmed death ligand 1 (PD-L1) immunohistochemical expression in colorectal cancer. Mol Diag Ther. 2016;20(2):175-81.

24. Park J-J, Omiya R, Matsumura Y, Sakoda Y, Kuramasu A, Augustine MM, et al. B7-H1/CD80 interaction is required for the induction and maintenance of peripheral T-cell tolerance. Blood. 2010;116(8):1291-8.

25. Butte MJ, Keir ME, Phamduy TB, Sharpe AH, Freeman GJ. Programmed death-1 ligand 1 interacts specifically with the B7-1 costimulatory molecule to inhibit T cell responses. Immunity. 2007 Jul;27(1):111-22. PubMed PMID: 17629517. Pubmed Central PMCID: PMC2707944. Epub 2007/07/17. eng

26. Pflughoeft KJ, Versalovic J. Human microbiome in health and disease. Annu Rev Pathol Mech Dis. 2012;7(1):99-122. PubMed PMID: 21910623

This work is licensed under a Creative Commons Attribution-NonCommercial 3.0 Unported License which allows users to read, copy, distribute and make derivative works for non-commercial purposes from the material, as long as the author of the original work is cited properly. 